How to Cite: Pirniyazov, K.K., Tikhonov, V.E., Rashidova, S.Sh. Synthesis and properties of oligochitosan ascorbate from Bombyx mori. Bulletin of the University of Karaganda-Chemistry, 101(1), 91-98. https://doi.org/10.31489/2021Ch1/91-98

UDC $678.5 ; 541.64$

\author{
K.K. Pirniyazov ${ }^{1 *}$, V.E. Tikhonov ${ }^{2}$, S.Sh. Rashidova ${ }^{1}$ \\ ${ }^{1}$ Institute of Chemistry and Physics of Polymers of the Academy of Sciences of the Republic of Uzbekistan, Tashkent, Uzbekistan; \\ ${ }^{2}$ Institute of Organoelement Compounds, Russian Academy of Sciences A.N. Nesmeyanov, Moscow, Russia \\ (*Corresponding author's e-mail: qudrat.pirniyazov@mail.ru)
}

\title{
Synthesis and properties of oligochitosan ascorbate from Bombyx mori
}

\begin{abstract}
Oligochitosan samples were obtained by acid hydrolysis of high molecular weight chitosan isolated from Bombyx mori (B.M.). Carrying out acid hydrolysis for 6 hours, it was found that after 4 hours and further with increasing duration, the molecular weight of chitosan decreases to a value corresponding to the ranges of molecular weights of oligochitosan $2-16 \mathrm{kDa}$. It has been seen that the optimal duration of hydrolysis, leading to the production of oligochitosan with a molecular weight of less than $16 \mathrm{kDa}$, should be considered 4-5 hours. Depolymerization of chitosan with a molecular weight of $177 \mathrm{kDa}$ was carried out using sodium nitrite in solution to obtain oligochitosan with a molecular weight of $6 \mathrm{kDa}$. On the basis of oligochitosan samples obtained by two methods, their ascorbates were received. Under constant conditions with varying the ratio of the components (ChS:AA) and the $\mathrm{pH}$ of the solution, the reaction of chitosan ascorbate formation was carried out on the basis of the suspension method. The composition, structure, and molecular weight characteristics of oligochitosan ascorbate and oligochitosan Bombyx mori samples were confirmed by physicochemical methods. It has been seen that the obtained samples have antimicrobial properties against Fuzarium oxysporum.
\end{abstract}

Keywords: Bombyx mori chitosan ascorbate, Bombyx mori oligochitosan, ascorbic acid, donor-acceptor bond, degree of binding, degrees of acetylation, depolymerization.

\section{Introduction}

One of the most promising and relevant areas of modern chemistry and technology is the production of water-soluble natural polymers, the study of the structure, properties, physical and chemical modifications, their application in various fields. The production of water-soluble chitosan derivatives expands the range of applications of this natural aminopolysaccharide in agriculture and biomedical sphere. The solubility of chitosan in water depends on a number of factors including the molecular weight and deacetylation degree (DD) of the polymer, the degree of protonation of amino groups in the macromolecule ( $\mathrm{pH}$ of the solution) [1,2]. Chitosan macromolecules are characterized by different molecular weights (degree of polymerization), degree of deacetylation, degree of protonation (pKa value), viscosity of solutions, arrangement of acetylated and deacetylated residues in the polymer chain and molecular weight distribution. Most of the mentioned characteristics affect the solubility of chitosan in water, while the manifestation of biologically active properties by chitosan largely depends on the solubility [3-4]. In [5, 6], the antibacterial activity of narrowly dispersed samples of oligochitosans, varying in molecular weight, at different $\mathrm{pH}$ values was studied. It was shown that under acidic conditions a stronger inhibitory effect is characteristic of samples with a higher molecular weight, while under slightly alkaline conditions, chitosan forms close to oligomeric are more active. It is assumed that the antibacterial activity of chitosan is determined by the protonation degree of its amino groups, which is variable and depends on both the molecular weight of the substance and the $\mathrm{pH}$ of the medium.

The analysis of numerous studies shows that the water solubility of low molecular weight chitosan (oligochitosan) increases with biological activity, especially antiviral and antibacterial activity, as well as biocompatibility with a decrease in molecular weight compared to the high molecular weight chitosan [6-8].

Chitosan derivatives are of great interest in the world, including chitosan ascorbate, which has bactericidal, growth-stimulating and antifungal properties. It should be noted that water-soluble forms of oligochitosan with organic acids have the most pronounced antimicrobial properties against the following bacteria: Streptococcus mutans, Lactobacilli brevis using in vitro and in vivo methods compared to similar forms of high molecular weight chitosans [9]. Chitosan ascorbate also has antioxidant properties against a number of bacteria, such as E. coli, P. aeruginosa, S. typhimurium, L. monocytogenes, and S. aureus at low concentrations [9-11]. In order to obtain biologically active, water-soluble derivatives of oligochitosans with ascorbic acid, the synthesis was carried out by the suspension method with varying the $\mathrm{pH}$ of the solution. 


\section{Experimental part}

Two samples of high molecular chitosan which were achieved from pupae of the silkworm Bombyx mo$r i$ with a molecular weight of $123 \mathrm{kDa}(\mathrm{ChS}-1)$ and $177 \mathrm{kDa}(\mathrm{ChS}-2)$ have been used in this experiment. The molecular weights of the samples were determined by viscometry, and the degree of deacetylation was measured by conductometric titration, where the value was $94 \%$ and $80 \%$, respectively. The degree of deacetylation was also confirmed by PMR spectroscopy. The molecular weight of the initial chitosan was determined by the viscometeric method using an Ubellode viscometer based on the Mark-Kuhn-Houwink equation, and the kinematic viscosities of the starting chitosans and oligochitosan were measured at constant temperature. The average weight (Aw) and average number (An) molecular weights of oligochitosan and oligochitosan ascorbate, and the value of the polydispersity index (pI) were determined by gel-penetrating chromatography. In this case, we used $0.3 \mathrm{M} \mathrm{CH}_{3} \mathrm{COOH} / 0.225 \mathrm{M} \mathrm{CH}_{3} \mathrm{COONH}_{4}(\mathrm{pH} 4.5)$ buffer solutions and hydrophilic polyvinylidene membranes for preliminary filtration of the analyzing solutions. Next, IR spectroscopic studies were carried out using an IR spectrometer from Bruker (Germany). The process of acid hydrolysis of chitosan ChS-1 in a solution of hydrochloric acid at $75^{\circ} \mathrm{C}$ for 6 hours was studied, while 6 samples were taken (variants were encrypted depending on the duration of the reaction, for example, ChS$1 / 1$ was taken from the reaction mixture for 1 hour) every 60 minutes. Oligochitosan ascorbate Bombyx mori (ChA-1 B.M.) was obtained on the basis of the formed oligochitosan by the acid hydrolysis method. The reaction of chitosan ascorbate formation was carried out on the basis of the suspension method under constant conditions with varying the ratio of the components (ChS:AA) and the $\mathrm{pH}$ of the solution [12]. The depolymerization of chitosan ChS-2 was carried out using an inorganic sodium nitrite salt in solution to obtain oligochitosan ChS-2/1 with a molecular weight of $6 \mathrm{kDa}$. The reaction was carried out at room temperature during 60 minutes. A chitosan derivative - oligochitosan ascorbate Bombyx mori (ChA-2 B.M.) was formed on the basis of the oligochitosan.

\section{Results and Discussion}

The results show that with an increase in the duration of the chitosan hydrolysis reaction, a significant decrease in the average number and weight mass of the obtained samples is observed up to $6 \mathrm{kDa} \mathrm{Mn}$ and $11 \mathrm{kDa} \mathrm{Mw}$. The degree of acetylation of the samples was determined by the PMR method. For this, oligochitosan samples were dissolved in $\mathrm{D}_{2} \mathrm{O}$, and chitosan samples - in $\mathrm{D}_{2} \mathrm{O}+\mathrm{DCl}$. The results obtained are presented in Table 1. The molecular weight and the degree of acetylation (DA) of the initial chitosan ChS- 1 are $123 \mathrm{kDa}$ and $20 \%$ according to the GPC and PMR data, respectively.

Table 1

The chromatography results of oligochitosan and oligochitosan ascorbate samples

\begin{tabular}{|c|c|c|c|c|c|c|c|}
\hline The samples & Synthesis time, $\min$ & $\begin{array}{c}\mathrm{Mn} \\
* 10^{3}\end{array}$ & $\begin{array}{c}\mathrm{Mw} \\
* 10^{3}\end{array}$ & $\begin{array}{c}\mathrm{Mz} \\
* 10^{3}\end{array}$ & $\begin{array}{c}\mathrm{Mp} \\
* 10^{3}\end{array}$ & $\begin{array}{c}\mathrm{pI} \\
(\mathrm{Mw} / \mathrm{Mn})\end{array}$ & $\mathrm{CA} \pm 1, \%$ \\
\hline ChS-1/1 & 60 & 15.9 & 28.3 & 41.5 & 28.5 & 1.77 & 16.7 \\
\hline ChS-1/2 & 120 & 11.8 & 22.1 & 34.3 & 19.0 & 1.88 & 15.3 \\
\hline ChS-1/3 & 180 & 13.0 & 21.7 & 31.7 & 21.8 & 1.67 & 14.0 \\
\hline ChS-1/4 & 240 & 8.56 & 15.6 & 24.7 & 9.28 & 1.82 & 13.8 \\
\hline ChS-1/5 & 300 & 8.16 & 14.1 & 22.0 & 9.15 & 1.73 & 9.1 \\
\hline ChS-1/6 & 360 & 6.06 & 10.8 & 18.2 & 5.60 & 1.75 & 9.0 \\
\hline ChSA-1 B.M. & 60 & 7.68 & 14.8 & 26.3 & 7.63 & 1.93 & 9.0 \\
\hline
\end{tabular}

As can be seen from the data obtained, with an increase in the duration of the reactions, a strong cleavage of the glycosidic and acetamide bonds of chitosan macromolecules occurs, therefore, due to depolymerization, a noticeable recession in the molecular weight and the degree of acetylation is observed. Carrying out acid hydrolysis for 6 hours, it was found that after 4 hours and further the molecular weight of chitosan falls to the value corresponding to the molecular weights of oligochitosan 2-16 kDa [6]. The yield of the final product comparing with the original chitosan is approximately $40 \%$ after 6 hours of hydrolysis. The optimal duration of hydrolysis under these conditions should be 4-5 hours. After the completion of the hydrolysis the product was isolated by sedimentation with an aqueous ammonia solution, followed by washing with distilled water. The oligochitosan ascorbate ChSA-1 B.M. was formed on the basis of obtained product. In order to compare the properties of the oligochitosan and its ascorbate, the oxidative 
depolymerization of chitosan ChS- 2 was carried out using a $0.2 \% \mathrm{NaNO}_{2}$ solution. The results show that the nitrite method causes deep depolymerization even at room temperature in a short time. The obtained oligochitosan ChS-2/1 was used to prepare oligochitosan ascorbate ChSA-2 B.M. The results are shown in Table 2.

Table 2

The results of chromatography of oligochitosan and oligochitosan ascorbate samples

\begin{tabular}{|c|c|c|c|c|c|c|c|}
\hline The samples & $\begin{array}{c}\text { Synthesis time, } \\
\text { min }\end{array}$ & $\begin{array}{c}\mathrm{Mn} \\
* 10^{3}\end{array}$ & $\begin{array}{c}\mathrm{Mw} \\
* 10^{3}\end{array}$ & $\begin{array}{c}\mathrm{Mz} \\
* 10^{3}\end{array}$ & $\begin{array}{c}\mathrm{Mp} \\
* 10^{3}\end{array}$ & $\mathrm{pI}(\mathrm{M} \omega / \mathrm{Mn})$ & $\mathrm{CA} \pm 1, \%$ \\
\hline ChS-2/1 & 60 & 4.13 & 5.93 & 8.23 & 4.0 & 1.46 & 9.6 \\
\hline ChSA-2 B.M. & 60 & 3.73 & 6.20 & 9.93 & 3.48 & 1.66 & 6.1 \\
\hline
\end{tabular}

The data given in the table above inform that the average number and average weight masses of the oligochitosan and oligochitosan ascorbate samples practically coincide. Also, during hydrolysis with sodium nitrite, in comparison with the acid hydrolysis method, the molecular weight characteristics of the samples decrease. Despite this, the literature data show that redistribution of functional groups is observed in the structure of oligochitosan, and aldehyde groups are also formed [11].

In addition to the GPC (gel-penetrating chramotography) data, the kinematic viscosity of the samples of the initial chitosan and its ascorbate was determined. For measurements, $1 \%$ aqueous solutions of the samples were prepared. Viscometers of the VPJ-2 type were used for measurements (the radius of the capillary is 0.34 or $1.31 \mathrm{~mm})$. Kinetic viscosity $\left(\mathrm{V}, \mathrm{mm}^{2} / \mathrm{s}\right)$ was calculated by the formula:

$$
\mathrm{V}=(\mathrm{g} / 9.807) \times \mathrm{K} \times \mathrm{T} \text {, }
$$

where: $\mathrm{K}$ is the constant of the viscometer, 0.0045632 or $0.30215 \mathrm{~mm}^{2} / \mathrm{s}^{2}$, respectively; $\mathrm{T}$ is the liquid flow time (s); $\mathrm{g}$ - acceleration due to gravity $\left(\mathrm{m} / \mathrm{s}^{2}\right)$. The obtained results are shown in the Table 3 .

$\mathrm{Table} 3$

Kinematic viscosity of samples of initial chitosans and oligochitosan ascorbates

\begin{tabular}{|c|c|c|c|c|c|c|}
\hline The samples & $\begin{array}{c}\text { Capillary } \\
\text { radius, } \mathrm{mm}\end{array}$ & $\begin{array}{c}\text { Solution } \\
\text { flow time, } \mathrm{s}\end{array}$ & $\begin{array}{c}\text { Kinetic viscosity, } \\
\mathrm{mPas}\end{array}$ & $\begin{array}{c}\text { Molecular weight } \\
\text { of samples, } \mathrm{kDa}\end{array}$ & $\begin{array}{c}\mathrm{N}, \% \\
\mathrm{C} \%, \\
\mathrm{AK}\end{array}$ \\
\hline ChS-1 & 1.31 & 39.0 & 13.0 & ${ }_{\Delta} \mathrm{M} 123$ & 8.36 & - \\
\hline ChS-2 & 1.31 & 59.0 & 19.6 & ${ }_{\Delta} \mathrm{M} 177$ & 8.56 & - \\
\hline ChSA-1 B.M. & 0.34 & 265.0 & 1.33 & $\mathrm{M}_{\omega} 14.8$ & 6.18 & 26 \\
\hline ChSA-2 B.M. & 0.34 & 233.0 & 1.17 & $\mathrm{M}_{\omega} 6.2$ & 4.10 & 52 \\
\hline
\end{tabular}

The results show that the kinetic viscosity of oligochitosan ascorbate ChSA-1 B.M. in comparison with the initial chitosan, ChS-1 decreases almost 10 times, and the kinetic viscosity of the obtained sample by the nitrite method decreases 16.7 times. The results indicate that oxidative depolymerization degrades the chitosan macromolecule more actively in comparison with acid hydrolysis. The ratio of oligochitosan was defined: ascorbic acid in the product was determined by elemental analysis for nitrogen content. The results show that with the growing of ascorbic acid content, a decrease in the amount of total nitrogen and kinetic viscosity of the samples is observed.

The structure of the samples was confirmed using IR and PMR spectroscopy. In order to compare the structural characteristics the IR spectra of the initial chitosans, oligochitosans, and their ascorbates have been obtained.

The results are shown in Figure 1. In the IR spectrum of chitosan (Fig. 1 b), characteristic absorption bands at 1645 and $1574 \mathrm{~cm}^{-1}$ were found corresponding to the functional groups of acetamide (amide I) and amine. In the range of $1310-1420 \mathrm{~cm}^{-1}$ and at $2900 \mathrm{~cm}^{-1}$, absorption bands of methylene groups were revealed. In the range $3200-3350 \mathrm{~cm}^{-1}$, absorption bands of the hydroxyl group were found. 


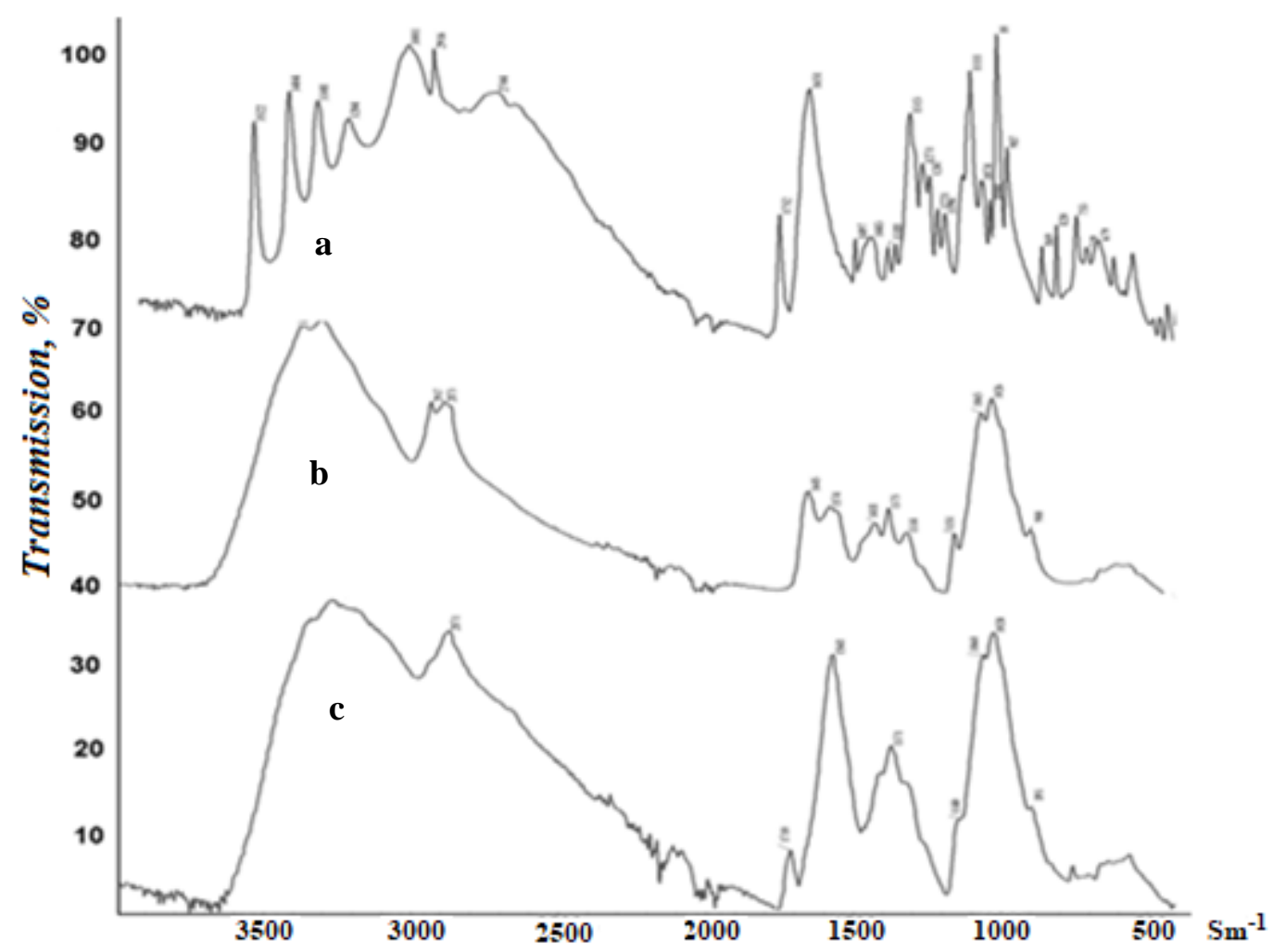

Figure 1. IR-spectra of ascorbic acid (a), chitosan-1 (b) and oligochitosan ascorbate Bombyx mori $(c)$

There are absorptions of stretching vibrations of C2 and C3 hydroxyl groups in the IR spectrum of ascorbic acid in the range of 3200-2900 $\mathrm{cm}^{-1}$. The absorption bands for the methylene group in the range of $2915-2900 \mathrm{~cm}^{-1}$ also have been found (Fig. 1.). At $1750 \mathrm{~cm}^{-1}$, an absorption band is observed for the carbonyl group included in the lactone ring of ascorbic acid; at $1650 \mathrm{~cm}^{-1}$ - absorption band characteristic of $\mathrm{C}=\mathrm{C}$ groups. Along with this, at 1320, 1270, $1140 \mathrm{~cm}^{-1}$, absorption bands of $\mathrm{C} 3-, \mathrm{C} 2-, \mathrm{C} 5$ - hydroxyl groups are found.

In the IR spectrum of the obtained oligochitosan ascorbate, a mixing of absorption bands appears, compared to the absorption bands of chitosan and ascorbic acid. Slight difference was observed due to the mixing of absorption bands towards lower wave numbers from 1645 and $1568 \mathrm{~cm}^{-1}$, which means the formation of oligochitosan ascorbate in the presence of amino groups. In the range of $1400-900 \mathrm{~cm}^{-1}$ absorption bands appear which are characteristic of chitosan with low intensity which indicate a decrease of the hydrogen bonds. The change in the intensity and shift of the characteristic absorption bands in the IR spectrum of oligochitosan ascorbate in comparison with the IR spectra of the initial components - ascorbic acid and chitosan - indicate the formation of a water-soluble derivative of chitosan - oligochitosan ascorbate.

NMR spectroscopic studies were also carried out. NMR spectra were recorded on a VARIAN-400 spectrophotometer (USA). In all experiments, the $\mathrm{D}_{2} \mathrm{O}$ solvents were used with the addition of DCl. It is known that the NMR spectra of chitosan are characterized by resonances in the range of 4.6-4.9 ppm, which coincide for the proton at $\mathrm{C}-1$, which indicates glucosidic bonds. Further, chemical shifts of the C-2, C-3, C-6 protons are observed in the range of $3.7-4.0 \mathrm{ppm}$. There are also resonances in the $3.2 \mathrm{ppm}$ and $-2.1 \mathrm{ppm}$ region, which correspond to the protons of the amino group and the acetamide group of this polysaccharide (Fig. 2) [12]. The obtained NMR spectra of the initial chitosan and oligochitosan are shown in Figures 3, 4.

The degrees of acetylation (DA) of the samples were also calculated. Based on the equation of $\mathrm{CA}=\mathrm{n} /(\mathrm{n}-100)=(0.1 / 3) /(1 / 6)=0.199$ then $1.199 \mathrm{n}=19.9$, and $\mathrm{n}=0.167$ or CA $(\%)=16.7 \%$. The results show a gradual decrease in the content of acetamide groups can be seen in the spectrum of the achieved oligochitosans, for example in the spectrum of samples ChS-1/6 (Fig. 3). 


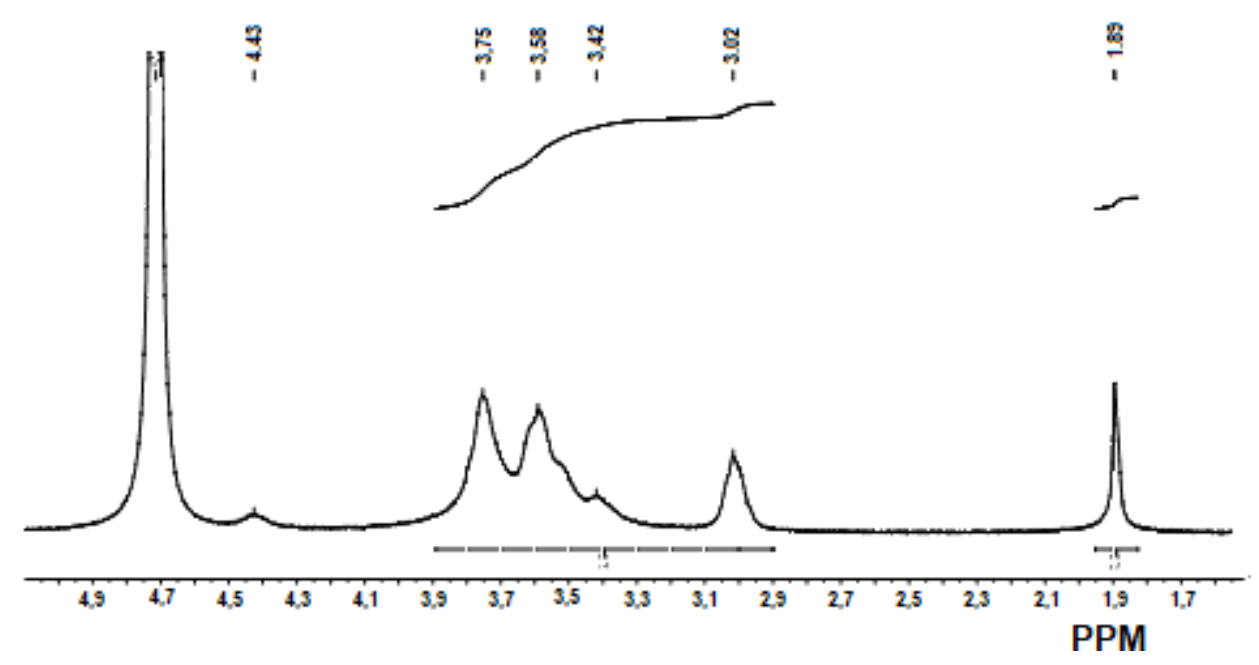

Figure 2. $\mathrm{H}^{1}$-NMR spectra of the initial chitosan ChS-1

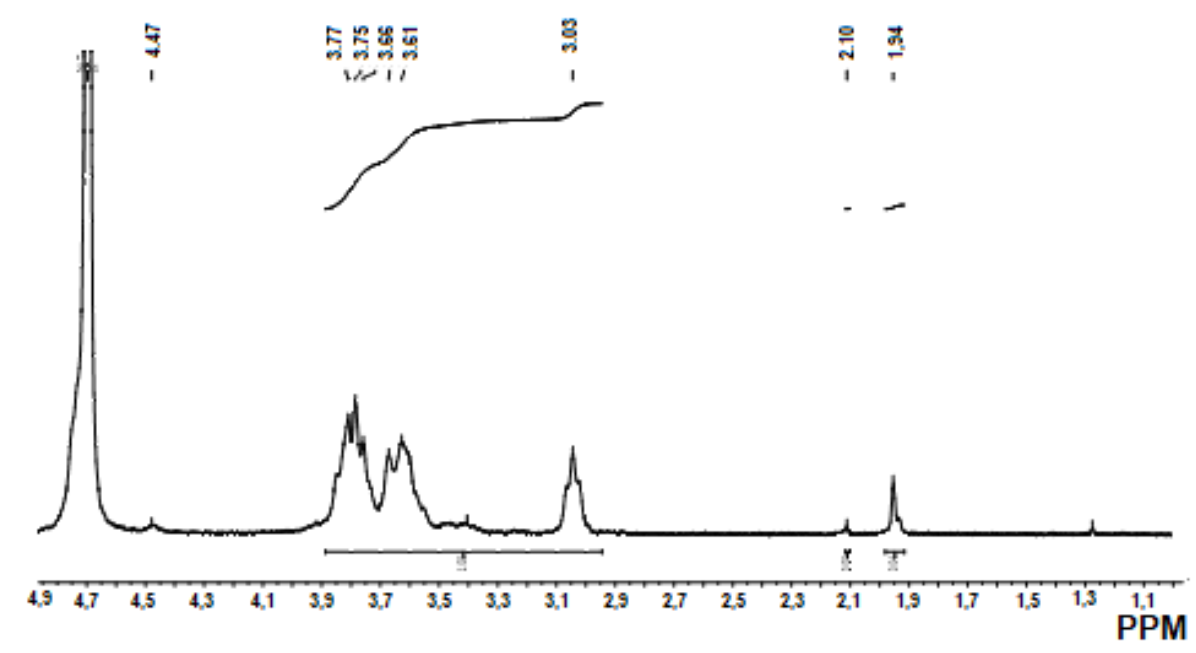

Figure 3. $\mathrm{H}^{1}$-NMR spectra of oligochitosan ChS-1/6

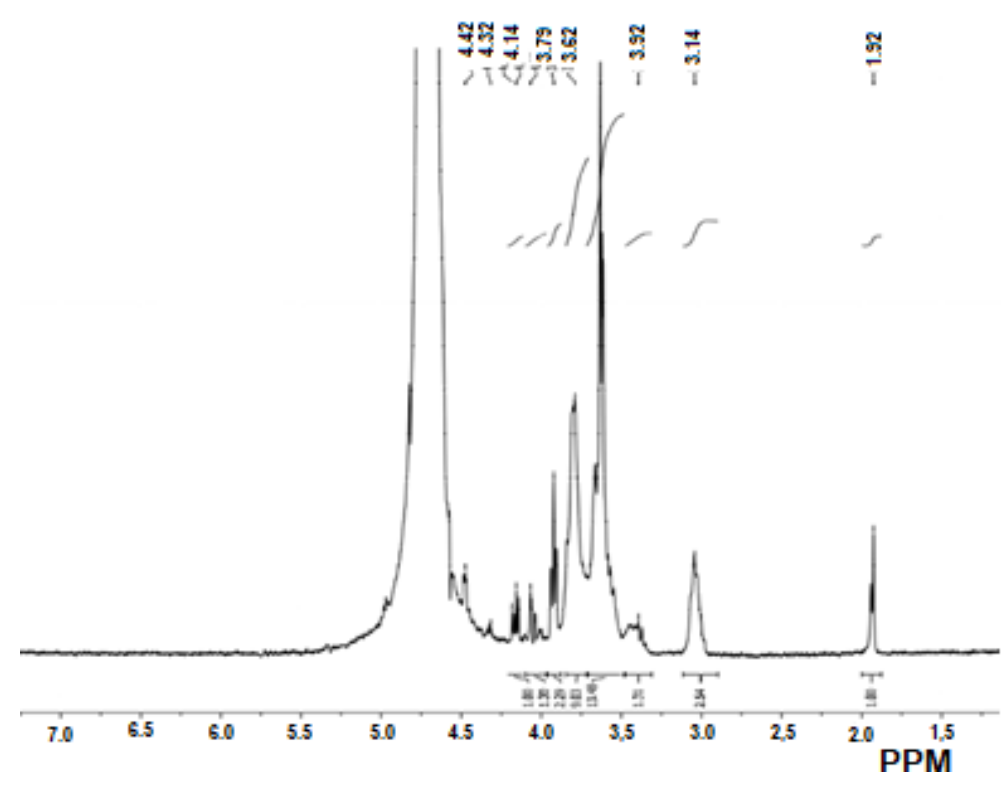

Figure 4. $\mathrm{H}^{1}$-NMR spectra of chitosan oligoascorbate ChSA-2 
As can be seen from the spectrum (Fig. 3), the degree of acetylation (DA) based on the equation $\mathrm{DA}=\mathrm{n} /(\mathrm{n}-100)=(0.05 / 3) /(1 / 6)=0.099$ then $1.099 \mathrm{n}=9.9$ and the value of the $\mathrm{n}=0.09$ or CA $=9 \%$. Thus, it can be concluded that as a result of acid hydrolysis up to 6 hours, the degree of acetylation decreases from $16.7 \%$ to $9 \%$.

In the NMR spectrum of oligochitosan ascorbate, a shift of signals compared to the signals of the initial oligochitosan from $2.8 \mathrm{ppm}$ to $3.1 \mathrm{ppm}$ was found, which can be explained by the interaction of the amino groups of oligochitosan with ascorbic acid $[12,13]$. An increase in the intensity of signals in the range of 3.5-4.1 ppm is also observed, which indicates the surge in the polydispersity of the sample and proton signals at C-6, C-5, C-4 due to the formation of oligochitosan ascorbate (Fig. 4.).

In the spectrum of ascorbic acid, characteristic signals are observed at $3.6 \mathrm{ppm}$, which correspond to the C-6 carbon protons and two protons in the $\mathrm{CH}_{2} \mathrm{OH}$ group of ascorbic acid molecules. Peaks 3.8, 3.9 ppm. refer to the protons associated with the C-4, C-5 and C-3 atoms of the lactone ring of ascorbic acid, respectively. The detected signals in the range of $4.9 \mathrm{ppm}$ correspond to protons at C-4 in the furanose ring of ascorbic acid, which corresponds to the literature data [13].

$0.5 \%$ solutions of oligochitosan ascorbate were prepared in order to realize these studies. Experiments were carried out on the basis of the obtained solutions 4 times. Certain biologically active properties of oligochitosan ascorbate showed that the obtained samples have antimicrobial properties against Fuzarium oxysporum in comparison with the reference and control. It was revealed that oligochitosan and oligochitosan ascorbate have antimicrobial properties, the zone of suppression of which is $22 \mathrm{~mm}$ on average, and no zone of suppression was found in the control (water).

\section{Conclusions}

Thus, the process of acid hydrolysis of chitosan ChS-1 in a solution of $1 \mathrm{M}$ hydrochloric acid at $75^{\circ} \mathrm{C}$ for 6 hours has been studied. It has been shown that the optimal duration of hydrolysis, leading to the production of oligochitosan with a molecular weight of less than $16 \mathrm{kDa}$, should be considered as 4-5 hours. Depolymerization of chitosan ChS-2 was carried out using sodium nitrite in solution to obtain oligochitosan with a molecular weight of $6 \mathrm{kDa}$. On the basis of the achieved oligochitosan samples by two methods, their ascorbates were prepared. The composition, structure, and molecular weight characteristics of oligochitosan ascorbate samples were confirmed by physicochemical methods. Certain biologically active properties of oligochitosan ascorbate showed that the obtained samples have antimicrobial properties against Fuzarium oxysporum in comparison with the reference and control.

This work was carried out with the financial support of the «El-Yurt Umidi» Foundation of the Republic of Uzbekistan. There is no conflict of interest. K.K. Pirniyazov with the leadership of S.Sh. Rashidova and V.E. Tikhonova carried out synthesis and calculations. All authors participated in data processing and in the discussion of the results.

\section{References}

1 Шиповская А.Б. Биологическая активность олигомеров хитозана / А.Б. Шиповская, В.И. Фомина, М.Н. Киреев, Е.С. Казакова, И.А. Касьян // Изв. Сарат. ун-та. Нов. сер. Химия. Биология. Экология. — 2008. — Т. 8, № 2. — С. 46-49.

2 Хитозан / под ред. К.Г. Скрябина, С.Н. Михайлова, В.П. Варламова. - М.: Центр «Биоинженерия» РАН, 2013. $591 \mathrm{c}$.

3 Куликов С.Н. Определения антибактериальной активности хитозана / С.Н. Куликов, Л.Т. Баязитова, О.Ф. Тюпкина, П.В. Зеленихин, М.М. Сальникова, Е.А. Безродных, В.Е. Тихонов // Прикладная биохимия и микробиология. - 2016. T. 52, № 5. - С. 1-7.

4 Куликов С.Н. Сравнительная оценка антибактериальных свойств олигохитозанов в отношении Klebsiella pneumonia / С.Н. Куликов, В.Е. Тихонов, Е.А. Безродных, С.А. Лопатин, В.П. Варламов // Биоорганическая химия. - 2015. - Т. 41, № 1. - C. 67-73.

5 Blagodatskikh I.V. N-Reacetylated Oligochitosan: $\mathrm{pH}$ Dependence of Self-Assembly Properties and Antibacterial Activity / I.V. Blagodatskikh, S.N. Kulikov, O.V. Vyshivannaya, E.A. Bezrodnykh, V.E. Tikhonov // Biomacromolecules. — $2017 . \quad-$ Vol. 18, No. 5. - P. 1491-1498. https://doi.org/10.1021/acs.biomac.7b00039

6 Tikhonov V.E. Bactericidal and antifungal activities of a low molecular weight chitosan and it is N-2/(3)-(dodec-2-enyl)succinoyl-derivatives / V.E. Tikhonov, E.A. Stepnova, V.G. Babak, I.A. Yamskov, et al. // Carbohydrate polymers. - 2006. Vol. 64. - P. 66-72. https://doi.org/10.1016/j.carbpol.2005.10.021

7 Kulikov S. Molecular weight and $\mathrm{pH}$ aspects of the efficacy of oligochitosan against methicillin-resistant Staphylococcus aureus (MRSA) / S. Kulikov, V. Tikhonov, I. Blagodatskikh, E. Bezrodnykh, S. Lopatin et al. // Carbohydrate Polymers. - 2012. Vol. 87. — P. 545-550. https://doi.org/10.1016/j.carbpol.2011.08.017 
8 Chih-Yu Chen. Antibacterial effect of water-soluble chitosan on representative dental pathogens Streptococcus mutans and Lactobacilli brevis / Chen Chih-Yu, Chung Ying-Chien // Journal Appl. Oral Sci. — 2012. — Vol. 20, No. 6. - P. 620-627. https://doi.org/10.1590/S1678-77572012000600006

9 Shipovskaya A.B. Novel antimicrobial drugs based on complex chitosan salts with chiral organic ligands / A.B. Shipovskaya, I.V. Zudina, V.I. Fomina, O.N. Malinkina // Butlerov Communications. - 2015. - Vol. 41, No. $3 . \quad-\quad$ P. 82. http://foundation.butlerov.com/bh-2015.

10 Tommeraas K. Preparation and characterization of oligosaccharides produced by nitrous acid depolymerization of chitosans / K. Tommeraas, K.M. Varum, B.E. Christensen, O. Smidsrod // Carbohydrate Research. — 2001. — Vol. 333. — P. $137-144$.

11 Pirniyazov K.K. Synthesis and structural characteristics of the ascorbate chitosan Bombyx mori / K.K. Pirniyazov, S.Sh. Rashidova // American journal of research. - USA, Michigan, 2019. - No. 7-8. - P. 114-119. DOI: http://dx.doi.org/10.26739/2573-5616-2019-8-10

12 Tian X.L. Synthesis and evaluation of chitosan-vitamin C complex / X.L. Tian, D.F. Tian, et al. / Indian J. Pharm Sci. 2009. — Vol. 71(4). — P. 371-376. https://doi.org/10.4103/0250-474X.57284

13 Шиповская А.Б. Новые антимикробные препараты на основе комплексной соли хитозана с хиральным органическим лигандом / А.Б. Шиповская, И.В. Зудина, В.И. Фомина, О.Н. Малинкина // Бутлеровские сообщения. — 2015. - Т. 41 , № 3. — C. 82-94. http://foundation.butlerov.com/bh-2015.

\title{
К.К. Пирниязов, В.Е. Тихонов, С.Ш. Рашидова \\ Bombyx mori-ден алынған олигохитозан аскорбатының синтезі және қасиеттері
}

\begin{abstract}
Олигохитозан сынамалары Bombyx mori-ден оқшауланған жоғары молекулалық хитозанның қышқылдық гидролизі арқылы алынды. 6 сағат ішінде қышқыл гидролизін жүргізгенде, 4 сағаттан кейін және одан әрі ұзақтығы артқан сайын хитозанның молекулалық салмағы олигохитозанның 2-16 кДа молекулалық салмақтарының диапазонына сәйкес мәнге дейін азаятындығы анықталды. Молекулалық салмағы 16 кДа-дан аз олигохитозан өндірісіне әкелетін гидролиздің оңтайлы ұзақтығын 4-5 сағат деп санау керек екендігі көрсетілген. Молекулалық салмағы 177 кДа хитозанды деполимерлеу натрий нитритін пайдаланып, молекулалық массасы 6 кДа олигохитозан алу үшін жүргізілді. Екі әдіспен алынған олигохитозан сынамалары негізінде олардың аскорбаттары синтезделді. Хитозан аскорбатының түзілу реакциясы суспензия әдісі негізінде компоненттердің (Х3:АА) және ерітіндінің рН қатынасының өзгеруімен тұрақты жағдайда жүргізілді. Олигохитозан аскорбат пен олигохитозан Bombyx mori сынамаларының құрамы, құрылымы және молекулалық сипаттамалары физикалық-химиялық әдістермен расталды. Алынған үлгілердің микробқақарсы әсері, яғни Fuzarium oxysporum-ға қарсы әсері бар екендігі дәлелденген.
\end{abstract}

Кілm сөздер: хитозан аскорбат Bombyx mori, олигохитозан Bombyx mori, аскорбин қышқылы, доноракцепторлық байланыс, байланыс дәрежесі, ацетилдену дәрежесі, деполимеризация.

\section{К.К. Пирниязов, В.Е. Тихонов, С.Ш. Рашидова}

\section{Синтез и свойства аскорбат олигохитозана из Bombyx mori}

Получены образцы олигохитозана кислотным гидролизом высокомолекулярного хитозана, выделенного из Bombyx mori. В ходе проведения кислотного гидролиза в течение 6 ч было обнаружено, что через 4 ч и далее с увеличением продолжительности молекулярная масса хитозана снижается до значения, соответствующего интервалам молекулярных масс олигохитозана 2-16 кДа. Показано, что оптимальной продолжительностью гидролиза, приводящего к получению олигохитозана с молекулярной массой менее 16 кДа, следует считать 4-5 ч. Осуществлена деполимеризация хитозана с молекулярной массой 177 кДа с помощью нитрита натрия в растворе с получением олигохитозана с молекулярной массой 6 кДа. На основе полученных двумя методами образцов олигохитозана синтезированы их аскорбаты. Реакция образования аскорбат хитозана проводили на основе суспензионном методом при постоянных условиях с варьированием соотношений компонентов (Х3:АК) и $\mathrm{pH}$ раствора. Состав, структура и молекулярно-массовые характеристики образцов аскорбата олигохитозана и олигохитозана Bombyx mori подтверждены физико-химическими методами. Показано, что полученные образцы обладают антимикробным действием против Fuzarium oxysporum.

Ключевые слова: аскорбат хитозана Bombyx mori, олигохитозан Bombyx mori, аскорбиновая кислота, донорно-акцепторная связь, степень связывания, степень ацетилирования, деполимеризация. 


\section{References}

1 Shipovskaya, A.B., Fomina, V.I., Kireyev, M.N., Kazakova, Ye.S., \& Kas'yan, I.A. (2008). Biolohicheskaia aktivnost olihomerov khitozana [Biological Activity of Chitosan Oligomers] Izvestiia Saratovskoho universiteta. Novaia seriia. Khimiia. Biolohiia. Ekolohiia - News of the Saratov University. Ser. Chemistry. Biology. Ecology, 8, 2, 46-49 [in Russian].

2 Skryabin, K.G., Mikhaylov, S.N., \& Varlamov, V.P. (2013). Khitozan [Chitosan]. Moscow: Tsentr «Bioinzheneriia» RAN [in Russian].

3 Kulikov, S.N., Bayazitova, L.T., Tyupkina, O.F., Zelenikhin, P.V., Sal'nikova M.M., Bezrodnykh, Ye. A., \& Tikhonov, V.Ye. (2016). Opredeleniia antibakterialnoi aktivnosti khitozana [Determination of the antibacterial activity of chitosan]. Prikladnaia biokhimiia i mikrobiolohiia - Applied Biochemistry and Microbiology, 52, 5, 1-7 [in Russian].

4 Kulikov, S.N., Tikhonov, V.Ye., Bezrodnykh, Ye.A., Lopatin, S.A., \& Varlamov, V.P. (2015). Sravnitelnaia otsenka antibakterialnykh svoistv olihokhitozanov v otnoshenii Klebsiella pneumonia [Comparative evaluation of the antibacterial properties of oligochitosans against Klebsiella pneumonia]. Bioorhanicheskaia khimiia - Bioorganic chemistry, 41, 1, 67-73 [in Russian]

5 Blagodatskikh, I.V., Kulikov, S.N., Vyshivannaya, O.V., Bezrodnykh, E.A., \& Tikhonov, V.E. (2017). N-Reacetylated Oligochitosan: pH Dependence of Self-Assembly Properties and Antibacterial Activity. Biomacromolecules, 18, 5, 1491-1498. https://doi.org/10.1021/acs.biomac.7b00039

6 Tikhonov, V.E., Stepnova, E.A., Babak, V.G., \& Yamskov, I.A. et al. (2006). Bactericidal and antifungal activities of a low molecular weight chitosan and it is $\mathrm{N}-2 /(3)-($ dodec-2-enyl)-succinoyl/-derivatives. Carbohydrate polymers, 64, 66-72. https://doi.org/10.1016/j.carbpol.2005.10.021

7 Kulikov, S., Tikhonov, V., Blagodatskikh, I., Bezrodnykh, E., \& Lopatin, S. et al. (2012). Molecular weight and pH aspects of the efficacy of oligochitosan against methicillin-resistant Staphylococcus aureus (MRSA). Carbohydrate Polymers, 87, 545-550. https://doi.org/10.1016/j.carbpol.2011.08.017

8 Chen Chih-Yu., \& Chung Ying-Chien (2012). Antibacterial effect of water-soluble chitosan on representative dental pathogens Streptococcus mutans and Lactobacilli brevis. Journal Appl. Oral Sci., 20, 6, 620-627. https://doi.org/10.1590/S167877572012000600006

9 Shipovskaia, A.B., Zudina, I.V., Fomina, V.I. \& Malinkina, O.N. (2015). Novel antimicrobial drugs based on complex chitosan salts with chiral organic ligands. Butlerov Communications, 41, 3, 82. http://foundation.butlerov.com/bh-2015.

10 Tommeraas, K., Varum, K.M., Christensen, B.E., \& Smidsrod, O. (2001). Preparation and characterization of oligosaccharides produced by nitrous acid depolymerization of chitosans. Carbohydrate Research, 333, 137-144.

11 Pirniyazov, K.K., \& Rashidova, S.Sh. (2019). Synthesis and structural characteristics of the ascorbate chitosan Bombyx mori. American journal of research, 7-8, 114-119. DOI: http://dx.doi.org/10.26739/2573-5616-2019-8-10

12 Tian, X.L., \& Tian, D.F. et.al. (2009). Synthesis and evaluation of chitosan-vitamin C complex. Indian J. Pharm Sci., 71 (4), 371-376. https://doi.org/10.4103/0250-474X.57284

13 Shipovskaya, A.B., Zudina, I.V., Fomina, V.I., \& Malinkina, O.N. (2015). Novye antimikrobnye preparaty na osnove kompleksnoi soli khitozana s khiralnym orhanicheskim lihandom [New antimicrobial drugs based on a complex chitosan salt with a chiral organic ligand]. Butlerovskie soobshcheniia - Butlerov communications, 41, 3, 82-94 [in Russian]. http://foundation.butlerov.com/bh-2015.

\section{Information about authors}

Pirniyazov, Kudrat Kadambayevich - Junior Researcher, Institute of Chemistry and Physics of Polymers of the Academy of Sciences of the Republic of Uzbekistan, 100128, Tashkent, A. Kadyri st, 7 b, Uzbekistan e-mail: qudrat.pirniyazov@ mail.ru https://orcid.org/0000-0002-3549-6363

Tikhanov, Vladimir Evgenevich - Candidate of chemical sciences, Leading researcher, Institute of Organoelement Compounds, Russian Academy of Sciences A.N. Nesmeyanova, 119991, Moscow, GSP-1, V-334, Vavilova st., 28, Russia. e-mail: tikhon@ineos.ac.ru

Rashidova, Sayyora Sharafovna - Doctor of chemical Sciences, Professor, Academician, Director of the Institute of Chemistry and Physics of Polymers of the Academy of Sciences of the Republic of Uzbekistan, 100128, Tashkent, A. Kadyri st, 7 b, Uzbekistan e-mail: polymer@academy.uz https://orcid.org/00000003-3104-6004 